\title{
CAN UTILITARIANISM JUSTIFY LEGAL RIGHTS WITH MORAL FORCE?
}

\author{
JOE MINTOFF ${ }^{\dagger}$
}

David Lyons has argued that utilitarianism cannot justify legal rights with moral force. ${ }^{1}$ He defined utilitarianism as the view that "the only sound, fundamental basis for normative (or moral) appraisal is the promotion of human welfare." ${ }^{2}$ He presented utilitarianism with the dilemma that even if it can morally justify the adoption of some legal institutions which grant rights, it cannot always morally justify the actions conforming to those legal institutions. This dilemma is structurally similar to one leveled against what we might call the economic theory of rationality. ${ }^{3}$

The economic theory of rationality may be defined as the view that the only sound, fundamental basis for rational appraisal is the promotion of the agent's welfare (where this may include the welfare of others). The dilemma leveled against this view is that even if it can rationally justify the adoption of some rule or disposition which governs action, it cannot always rationally justify the actions conforming to that rule or disposition. ${ }^{5}$ A distinctive type of response has recently been suggested to this dilemma. ${ }^{6}$ The key feature of this response is

+ Lecturer, School of Liberal Arts, University of Newcastle, Australia.

' David Lyons, Utility and Rights, in ETHICS, ECONOMICS, AND THE LAW: NOMOS XXIV 107, 109 (J. Roland Pennock \& John W. Chapman eds., 1982).

${ }_{2}$ Id. at 107. I shall focus only on moral appraisal, since some normative appraisals are not moral (for example, rational or aesthetic appraisals), and utilitarianism is most often understood as a theory providing moral appraisals.

${ }^{9}$ Cf. DeREK PARfIT, REASONS AND PERSONS 12-13 (1984) (providing an example that sometimes it is rational to act irrationally).

${ }^{4}$ See id. at 16 (describing the objection that an adequate theory must not have this implication).

${ }^{5}$ For the substantive aims of a theory of rationality, see DAVID GAUTHIER, MORALS BY AGREEMENT 21 (1986); PARFIT, supra note 3, at 3.

${ }^{6}$ See David Gauthier, Commitment and Choice: An Essay on the Rationality of Plans, in ETHICS, RATIONALITY AND ECONOMIC BEHAVIOUR 217 (Francisco Farina et al. eds., 1996) [hereinafter Gauthier, Commitment and Choice] (setting forth a theory of rational commitment); David Gauthier, Rationality and the Rational Aim, in READING PARFIT 24 (Jonathan Dancy ed., 1997) (critiquing Parfit's claims about the self-interest theory); David Gauthier, Resolute Choice and Rational Deliberation: A Critique and a Defense, 31 Nous 1 (1997) [hereinafter Gauthier, Resolute Choice and Rational Deliberation] (looking at the effects of shifting preferences). For alternative approaches to these issues, see 
the idea of an intention (commitment, resolution), the adoption of which may be rationally justified by the agent's welfare, and the existence of which may rationally justify actions fulfilling it. In my view, this recent response goes a long way toward resolving the dilemma faced by the economic theory of rationality. ${ }^{7}$ So too, perhaps, a structurally similar response may go some way toward resolving Lyons's dilemma for utilitarianism. The aim of this Article is to investigate this possibility.

\section{A DILEMMA FOR UTILITARIANISM}

I shall start by briefly explaining what Lyons means by legal rights with moral force, and why he claims utilitarianism cannot justify such rights. " Lyons focuses on very ordinary rights to make his case. "Suppose," he says,

that Mary rents a house that comes with a garage for her car. Access to the garage is provided by a private driveway, which she alone is authorized to use. Sometimes, however, she finds someone else's car parked in the driveway, which prevents her from parking or leaving with her own car. This may be inconvenient or it may not. Whenever it happens, however, Mary's rights are not being respected by other individuals.

Lyons's general understanding of rights is that a person has a right over something when she is permitted to use it as she wishes and when others are permitted to use it only with her permission (subject to limitations to be introduced below). The rights which Lyons considers have four important features.

First, they are legal rather than moral rights. ${ }^{10}$ Some rights exist independently of social recognition and enforcement; these rights are moral rights and may include human rights (which people have simply in virtue of being human) and rights that depend on particular circumstances (such as rights generated by promises). Other rights require some sort of social recognition or enforcement for their exis-

Edward F. McClennen, Pragmatic Rationality and Rules, 26 PHIL. \& PUB. AFF. 210 (1997); Derek Parfit, Bombs or Coconuts, or Rational Irrationality, in PRACTICAL RATIONALITY AND PREFERENCE: ESSAYS FOR DAVID GAUTHIER 81 (Christopher W. Morris \& Arthur Ripstein eds., 2001).

${ }^{7}$ See Joe Mintoff, Rational Cooperation, Intention and Reconsideration, 107 ETHICs 612 (1997) (examining rational choice).

${ }^{8}$ For a more general formulation of the problem utilitarianism faces, see Larry Alexander, Pursuing the Cood-Indirectly, 95 ETHICS 315 (1985).

${ }^{9}$ Lyons, supra note 1 , at 113-14.

${ }^{10}$ Id. at 108-09. 
tence. Rights conferred by law are a clear example of such rights. Clearly, Mary's right over her driveway depends on social recognition, and therefore it is a legal right.

Second, Lyons focuses only on morally justified legal rights. A person's legal right to something is morally justified when the legal institution (or the relevant part thereof) which recognizes or enforces that right is itself morally justified. This allows for the possibility that some legal rights are not morally justified-Lyons himself gives the obvious example of the rights accorded by the institution of chattel slavery. ${ }^{11}$ Presumably, however, at least some legal rights are morally justifiedLyons takes Mary's rights over her garage and driveway as an example, assuming that "the social arrangements presupposed by Mary's rights and their enforceability are justifiable; those institutions or their relevant parts are morally defensible." 12

Third, these legal rights have what he calls moral force. Lyons explains how this notion operates in relation to moral rights as follows:

If I have a right to do something, this provides an argumentative threshold against objections to my doing it, as well as a presumption against others' interference. Considerations that might otherwise be sufficient against my so acting, in the absence of my having the right, or that might justify others' interference, are ineffective in its presence.

... I call this argumentative threshold character the normative force of moral rights. ${ }^{13}$

This suggests that whether or not a person's legal right to something has moral force is dependent on the circumstances. For example, if a person lacks a particular legal right, certain actions are morally justified, but if she has that legal right (all other things being equal) then those actions are not morally justified. Mary's legal rights over her driveway have moral force: she is morally justified in using her driveway, and others are morally required to ask her before using the driveway; but neither would be the case if Mary had no rights over the driveway. Legal rights with moral force make a moral difference. ${ }^{14}$

Finally, however, the moral force of legal rights is typically limited. "The driver of an emergency vehicle on an urgent errand might justifiably block Mary's driveway without first obtaining Mary's permis-

1 See id. at 118 (noting that even if chattel slavery were legal, it would nevertheless be morally unjustifiable).

12 Id. at 114 .

13 Id. at 111.

${ }^{14}$ As we shall see, infra text accompanying note 18 , Lyons is inclined to make a connection from legal rights being morally justified to their having moral force. 
sion-even, perhaps, in the face of her refusal to give permission. This holds from both a legal as well as a moral standpoint." ${ }^{15}$ If Mary is not herself a utilitarian, then what she wishes to do with her rights will often depart to some degree from what would maximally promote human welfare. The moral force of her legal rights is limited in the sense that if what she wishes to do departs substantially from what would maximally promote welfare, then she is morally required to promote welfare. However, as Lyons notes, this does not imply that if what she wishes to do departs minimally from what would maximally promote welfare, then she is morally required to forgo her rights. While Mary's rights are not absolute, they do mean something morally.

In sum, then, Lyons focuses on morally justified legal rights with (limited) moral force. Given this, we can now see why Lyons thinks utilitarianism cannot always morally justify the actions that conform to morally justified legal institutions, and why he thinks this is a dilemma for utilitarianism. There are three prongs to the dilemma he presents.

First, as we have seen, he defines utilitarianism as the view that the only sound, fundamental basis for moral appraisal is the promotion of human welfare. This implies that an institution is morally justified when it promotes human welfare no less efficiently than any alternative institution. Similarly, it implies that an action is morally justified under equivalent conditions when it promotes human welfare no less efficiently than any alternative action. Both institutions and actions are to receive direct utilitarian appraisal.

Second, the legal institutions which maximally promote human welfare will inevitably permit (if not require) actions which do not maximally promote human welfare. "[I]t is predictable," says Lyons, "that real social rules that are supported by the best utilitarian . . arguments will require decisions in particular cases that would not most effectively promote welfare or efficiency. Such goals can sometimes be promoted more effectively by departing from the rules, or by changing them." Though Lyons himself does not say why this should be inevitable, it is easy to supply reasons that support this proposition. In the first place, all institutions are necessarily imperfect and as such unintentionally require actions which do not promote human welfare. The adoption and operation of any institution comes with costs; if the

\footnotetext{
${ }^{15}$ Lyons, supra note 1 , at 115 .

${ }^{16} I d$. at 123 .
} 
costs are not to be prohibitive, not all possible circumstances can be considered when it is being adopted and while it is operating. And it is inevitable that among the unconsidered circumstances will be ones in which the institution requires actions which do not promote human welfare. In the second place, some institutions-the prime examples being those which function to encourage or deter behaviorare most effective when they intentionally focus on something other than the promotion of human welfare. Any such institution comes with effects on the behavior of those subject to that institution; if the institution is to have optimal effects on this behavior, the distribution of rewards and punishments must be to some extent dependent on the performance of desirable or undesirable actions (and so must to some extent be independent of whether the distribution itself maximally promotes human welfare). Thus, it is inevitable that some of the rewards and punishments distributed will not promote human welfare. In either of these ways, then, best utilitarian legal institutions will sometimes permit (or even require) nonbest utilitarian actions.

These first two claims imply that, even if utilitarianism can morally justify the adoption of legal institutions which grant rights, it cannot always morally justify the actions conforming to those legal institutions.

Suppose, for example, that a neighbor decides late at night to park his car in Mary's driveway, without obtaining her permission, in order to save himself a long cold walk from the nearest legal parking space. He might reason soundly that Mary is unlikely to be inconvenienced, since he shall move his car early the next morning. And that might turn out to be the case. ${ }^{17}$

Now utilitarianism can, Lyons supposes, morally justify the legal institution which grants Mary rights to the exclusive use of the driveway in this case. Perhaps it was not worth the time of the utilitarian lawmakers to consider the details of such a case, or perhaps they did consider the details and concluded that people would be more likely to respect rights in more important cases if those rights were extended to include less important cases such as this one. However, utilitarianism cannot morally justify the actions conforming to that legal institution. For while it is perfectly clear that Mary's right to the driveway implies that her neighbor is not legally permitted to use the driveway (assuming Mary is not prepared to give permission), it is equally clear that her neighbor's use of the driveway would maximally promote human

${ }^{17}$ Id. at 116. 
welfare (Mary is unlikely to find out, and it is a long way to walk in the cold). Since this reasoning applies in any case in which it would maximally promote welfare not to respect her rights, Mary's morally justified legal rights have no moral force for the utilitarian.

Third, and here we come to the dilemma, Lyonis claims that morally justified legal rights automatically have moral force.

The principal assumption I shall make is this. When we regard Mary's rights as morally defensible, on any basis whatsoever, we also regard them as having moral force. The differences that her rights make to evaluation of conduct obtain, not just in the eyes of the law, but also from a moral point of view... To deny that Mary's legal rights have such force is to deny that they are morally defensible. ${ }^{18}$

Thus, more generally, if a legal institution which recognizes or enforces a right is morally justified, then exercising that right is also morally justified. This principle postulates a justificatory moral bridge from institutions to actions in conformity with those institutions. Under this view, the utilitarian position that Mary's morally justified legal rights have no moral force is mistaken.

How might the utilitarian respond to this dilemma? To help us answer this question, I shall consider a structurally similar dilemma for the economic theory of rationality.

\section{A DILEMMA FOR THE ECONOMIC THEORY OF RATIONALITY}

Lyons's discussion of rights involves ideas which are central to David Gauthier's discussion in Morals by Agreement of the so-called principle of constrained maximization. ${ }^{19}$ The dilemma in this case is that the economic theory of rationality cannot always rationally justify the actions conforming to rationally justified rules or dispositions. As above, there are three statements we need to consider.

18 Id. at 114-15.

19 The principle of constrained maximization says that, in certain circumstances, it is rational to act in compliance with a rational agreement even when it would be advantageous to refrain from holding up your end of the bargain. GAUTHIER, supra note 5 , at 15 .

${ }^{20}$ We may also note in passing that constrained maximization has features analogous to the four features of rights which Lyons identifies. Just as Lyons focuses on those rights a society chooses to recognize or enforce, Gauthier focuses on those dispositions, including the disposition to constrained maximization, an individual chooses to adopt. $I d$. at 183 . Just as Lyons supposes that the moral justification of rights is identical to the moral justification of the institutions which grant those rights, allowing for the utilitarian character of such justification, Gauthier supposes that the rational justification of the principle of constrained maximization is identical to the 
First, according to the economic theory of rationality, the only sound, fundamental basis for rational appraisal is the promotion of the agent's welfare, where this may include the welfare of others. ${ }^{21}$ This implies that a rule, disposition, or action is rationally justified when it promotes the agent's welfare no less efficiently than any alternative rule, disposition, or action would.

Second, it may be that the rule or disposition which maximally promotes an agent's welfare requires actions which do not maximally promote her welfare. ${ }^{22}$ Here is a story to illustrate this proposition: Mario lives across the road from Mary. Due to financial difficulties the city has been.having, it has become common knowledge that the city no longer enforces parking regulations. This means there is the chance of mutual benefit: Mary wants to continue enjoying the benefits of the exclusive use of her driveway, and Mario has just lost his job at a security firm. So Mario would like to offer Mary that he will make sure no one uses her driveway without her permission if she is prepared to pay an up-front fee. In short, Mario proposes to follow the rule that he will stop anyone from using Mary's driveway without her permission in exchange for Mary's money. Acting on this rule will not maximally promote Mario's welfare: there is some risk he will be led into conflict, possibly violent, with Mary's neighbors, and anyway, Mario knows that Mary is moving away soon, so he is unlikely to suffer ill-repute amongst his local community were he to do nothing. For

rational justification of the disposition which would embody that constraint, insisting on the utility-maximizing character of such justification. Id. at 170. Just as Lyons claims that morally justified legal rights make a difference in themselves to what it is moral to do, Gauthier claims that constrained maximization, if rationally justified, makes a difference in itself to what it is rational to do: "We shall consider whether particular choices are rational if and only if they express a rational disposition to choose." Id. at 183. And just as Lyons admits that there are moral limits to respecting morally justified rights, Gauthier has come to see that there are rational limits to acting on rationally justified dispositions, arguing that

it is rational to honor an assurance that at the time of performance one does not expect to lead to one's life going as well as possible ... if but only if at that time one expects honoring it to lead to one's life going better than had one given no assurance at all.

David Gauthier, Assure and Threaten, 104 ETHICS 690, 704 (1994). But see GAUTHIER, supra note 5 , at 186 (providing a previously held, contrary view in arguing that "[i]f her dispositions to choose are rational, then surely her choices are rational").

${ }^{21}$ For a discussion of the substantive aims of a theory of rationality, see GAUTHIER, supra note 5, at 21; PARFIT, supra note 3 , at 3.

${ }^{22}$ See David Gauthier, Why Contractarianism?, in CONTRACTARIANISM AND RATIONAL Chotce: Essays on DAVId GAUTHIER's “Morals bY AGReEMENT" 15, 24 (Peter Vallentyne ed., 1991) (justifying a contractarian approach to the rationality of moral constraint). 
Mario to fulfill his offer, he must be prepared to forgo the benefit of simply taking the money and then doing nothing. In spite of this, being disposed to follow the rule may maximally promote Mario's welfare, for Mary may be sufficiently likely to discover, before she hands over the money, whether Mario really is disposed to follow the rule he proposes-perhaps Mario cannot lie to save his life or is, for some other reason, sufficiently translucent. For Mario to get the money, he really does have to be disposed to forgo the benefits of cheating.

The first two statements imply that, even if the economic theory of rationality can rationally justify the adoption of rules or dispositions, it cannot always rationally justify the actions conforming to them. Since being disposed to follow his rule maximally promotes Mario's welfare, this theory implies that Mario rationally ought to adopt this rule. But since acting on his rule does not maximally promote his welfare, this theory also implies that he rationally ought not to act on the rule. In other words, according to the economic theory, Mario's rationally justified rule has no rational force and makes no difference to what he rationally should do.

The third prong of the dilemma is that it is incoherent to claim that a person rationally ought to adopt a rule she rationally ought not to act on. There are more or less complex ways of making this point. At one time, Gauthier endorsed the claim that

[i]f it is rational for me to adopt an intention to do $x$ in circumstances $c$, and if $c$ come about, and if nothing relevant to the adoption of the intention is changed save what must be changed with the coming about of $c$. . [,] then it is rational for me to carry out $x^{23}$

More recently, he has endorsed the idea that it is rational to act on a previously formed intention when doing so still leaves one better off than if one had not formed that intention in the first place. ${ }^{24}$ Whatever the details, both reject the view that, since forming an intention and acting on the intention are separate things, a rational or moral assessment of the first may be independent of an assessment of the second, and so it may be rational to form an intention to perform irra-

23 David Gauthier, Afterthoughts, in THE SECuRITY GAMBLE: DETERRENCE Dilemmas IN THE NuCleAR AGE 159, 159 (Douglas Maclean ed., 1986); see also GAUTHIER, supra note 5, at 183 (discussing the concept of a "constrained maximizer").

${ }^{24}$ See Gauthier, supra note 20, at 702 (claiming that, even where "rational deliberation may prove self-defeating in relation to [an] aim," the deliberation also allows an objection to determine which action will prove most conductive to the aim, minimizing the self-defeating effects). 
tional actions. ${ }^{25}$ Commenting on this view, Gauthier says that such is "a schizophrenic view of rationality and morality." ${ }^{26}$ If someone realizes right at the start that it would be irrational to act in some way, he asks, then how can she form an intention to act in that way? More generally, if a rule or disposition is rationally justified, then acting on it is also rationally justified. There is, on this type of view, a justificatory bridge from rules and dispositions to the actions in conformity with those rules and dispositions.

\section{The ECONOMIC THEORY AND VOLUnTARY RuleS}

In my view, this dilemma for the economic theory of rationality can be resolved. Recent accounts of practical reason show how an agent might both rationally adopt a rule or disposition because adopting it promotes her welfare and rationally act on it even though acting on it does not. In this Part, I introduce one such account of practical reason, but provide only the details necessary to illustrate its application to the dilemma Lyons presents for utilitarianism. I leave the defence of it for other places. ${ }^{27}$

The key idea underlying this recent account is that intentions (commitments, resolutions) have a central role in practical reasoning. Following the approach of Michael Bratman, we may define intentions by the functional roles they play. ${ }^{28}$ First, intentions are what Bratman calls volitional:

Intentions are, whereas ordinary desires are not, conduct-controlling proattitudes. Ordinary desires, in contrast, are merely potential influencers of action .... If my future-directed intention manages to survive until the

${ }^{25}$ See David Lewis, Devil's Bargains and the Real World, in THE SECURITY GaMble: DETERRENCE DILEMMAS IN THE NUCLEAR AGE, supra note 23, at 141, 141 (providing an account of the conditions under which it is rational to persist with an intention).

${ }^{26}$ Gauthier, supra note 23, at 160 ; see also PARFIT, supra note 3, at 16 (giving an example of a situation in which the actor "cannot avoid acting irrationally").

${ }^{27}$ See, e.g., Michael E. Bratman, Intention, Plans, and Practical Reason 60106 (1987) (defending a historical account of rational-intention formation and reconsideration); Gauthier, Commitment and Choice, supra note 6, at 243 (concluding that "[e]ffective planning requires commitments to choices that are not directly supported by preferences for their outcomes"); Gauthier, Resolute Choice and Rational Deliberation, supra note 6 , at 1 (discussing his interest in "characterizing rational deliberation in the face of changing evaluations of possible outcomes arising from anticipated or experienced preference shifts"); Mintoff, supra note 7, at 612 (introducing the intention to develop a "plausible contractarian account of rational choice").

${ }^{28}$ See BRATMAN, supra note 27, at 9 (describing his functionalist approach to intention). 
time of action, and I see that that time has arrived and nothing interferes, it will control my action then. ${ }^{29}$

Bratman puts the point in third-personal terms: my intentions control and guide my conduct. ${ }^{30}$ It will be useful later on if we also put the same point in first-personal terms: my plans (that is, my conception of what I am to do, which is the object of my intention) control and guide my conduct. ${ }^{31}$ Second, and obviously closely related to their ability to control future action, is the fact that intentions have a characteristic (revocable) stability: "Lacking new considerations[,] I will normally simply retain my intention up to the time of action. Retention of my prior intention and nonreconsideration is, so to speak, the 'default option." "'2 Third, there are the roles that intentions play in practical reasoning. Intentions are what Bratman calls means-end coherent, in that intentions are often partial to start off with, and typically get filled in as time goes by with further intentions: "I will frequently reason from the intended end to intended means or preliminary steps .... And I will frequently reason from more general to more specific intentions ...." Again, from a first-personal perspective, my plans are often partial to start off with, and typically get filled in as time goes by with more details. Furthermore, intentions are consistency-constrained, both amongst themselves and relative to one's beliefs: "[M]y prior intention to go to Tanner this afternoon will constrain the other intentions I form for the day, since I will seek to make my intentions consistent with one another and with my beliefs." ${ }^{34}$ Again, from the firstpersonal perspective, I seek to make my plans consistent with one another and with what I take to be the case. Since Mele offers a similar

29 Id. at 16; see also Alfred R. Mele, Intention, Belief, and Intentional Action, 26 AM. PHIL. Q. 19, 20-23 (1989) (arguing that intention serves as both a motivating and guiding force behind intentional actions).

30 BRATMAN, supra note 27, at 28-29.

31 The term "plan" may refer, on the one hand, to an intention or, on the other, to a (possible) object of intention. Thus, if I intend to go to the beach, then my plan ambiguously refers to either my intention or my action of going to the beach. Bratman adopts the first altemative, but I shall adopt the second. Thus, I shall say that if I intend to go to the beach, then my plan is to go to the beach.

${ }^{32}$ BRATMAN, supra note 27, at 16-17; see also Mele, supra note 29, at 25 (commenting that "[i]ntending to $A \ldots$ is partially constituted by being settled upon $A$-ing, or at least upon trying to $A$ ").

${ }^{33}$ BRATMAN, supra note 27, at 17; see also Mele, supra note 29, at 23-24 (discussing intentions as prompters and terminators of practical reasoning).

${ }^{34}$ BRATMAN, supra note 27 , at 17. 
list, ${ }^{35} \mathrm{I}$ assume Bratman has indeed captured the functions distinctive of intentions.

Of course, these functions are not always perfectly fulfilled. I planned to stop smoking, but sometimes temptation gets the better of me; some plans I have no inclination at all to act on anymore, sometimes it takes me a while to get around to implementing a plan, and sometimes I accidentally double-book myself. In some such cases we will say that I no longer have the relevant intention (for example, when I lack any inclination at all), in other cases that I still have the intention (for example, my intention to stop smoking, if I regret my weakness and take steps to ensure that it doesn't happen again), and in yet other cases we will not be sure (for example, if my procrastination lasts long enough). The important thing to note is that an individual does not need to be perfect in order to have intentions.

The most important thing for our purposes is the role that intentions play in practical reasoning. "Prior intentions and plans ... provide a background framework against which the weighing of desire-belief reasons for and against various options is to take place." ${ }^{36}$ In deliberating about what to do, one starts with a background of prior intentions (which one takes as fixed during deliberation) and a set of options, each of which one believes one has the ability to perform. These prior intentions play a role in practical reasoning by restricting this original set of options to a set of relevant and admissible options. Now, as we have seen, since my intentions are typically not fully specific, executing them will require that I form subintentions as a means of fulfilling them: the options relevant to a certain intention are, roughly, those which can contribute to the fulfilling of that intention. Further, as we have also seen, since my intentions need to be consistent with one another, an intention I already have will constrain the various options I may adopt in fulfilling the original intention: the admissible options, roughly, are the ones the performance of which is consistent (according to one's beliefs) with the fulfillment of one's prior intentions. At least while these prior intentions remain, deliberation occurs only amongst relevant and admissible options, and the aim of deliberation is the usual one of trying to discover the (relevant and admissible) option which maximally promotes one's welfare. One's prior intentions provide a filter on the options over which one deliberates.

${ }^{35}$ See Mele, supra note 29 , at 20-24 (listing intentions as "initiating and sustaining motivators of . . . action," "guides and monitors," "elements in coordinative plans," and "prompters and appropriate terminators of practical reasoning").

36 BRATMAN, supra note 27, at 33-34. 
How does this help resolve the dilemma for the economic theory of rationality? First, we note that Mario rationally should form an intention to enforce Mary's rights over her driveway, if this does not commit him to too much. To see this, we need to recall two things: that his forming the intention will maximally promote his welfare (remember that Mary may be "sufficiently" likely to discover, before she hands over the money, whether Mario is sincere); and that acting on the intention does not maximally promote his welfare (remember that enforcing Mary's rights comes at some risk of bodily harm, and that Mary is moving away soon anyway). This then implies two things: that not forming this intention exhibits a certain degree of constraint (that is, it forgoes a certain amount of welfare in comparison to what would maximally promote his welfare (namely, forming the intention)-it forgoes the money Mary would pay him); and that acting on this intention also exhibits its own degree of constraint (it also forgoes a certain amount of welfare in comparison with what would maximally promote his welfare (namely, not acting on it)-it forgoes security from possible violent confrontation with Mary's neighbors).

Two possibilities flow from the above statements. On the one hand, the degree of constraint exhibited by not forming the intention may be greater than that exhibited by acting on the intention. Mario, in other words, loses more by not forming the intention than by acting on it. In this case, Mario rationally ought to form the intention. On the other hand, the degree of constraint exhibited by not forming the intention may be smaller. Mario, in other words, loses more by acting on the intention than he would by not forming it in the first place. In this case, Mario rationally ought not to form the intention, since it commits him to too much. In sum, Mario should form the intention which minimizes the amount of his own forgone welfare. Such is a thumbnail sketch of what $I$ have argued elsewhere ${ }^{37}$ is the correct account of the conditions under which one rationally ought to form an intention. ${ }^{38}$ Let us suppose, therefore, that acting on the intention would not cost Mario too much and that Mario forms this intention.

${ }^{37}$ See Mintoff, supra note 7, at 635-42 (examining rational-intention formation).

${ }^{38}$ Note that Bratman himself would not endorse this account. See BRATMAN, supra note 27, at 85 (introducing the historical principle of deliberative rationality). But see Joe Mintoff, On a Problem for Contractarianism, 74 AUSTRAlasian J. PHIL. 98 (1996) (arguing that the pragmatic rationale Bratman provides for intentions (relating to decision costs and intra- and interpersonal coordination) implicitly includes forming commitments on the basis of their utility). 
Second, we note that Mario will have no rational justification for reconsidering his intention if things proceed exactly as he expected (as they might). We may distinguish two accounts of the conditions under which reconsideration is rational. First, according to a changeof-expectation account, the rationality of reconsidering an intention depends on whether or not one has changed, or rationally ought to have changed, a belief or expectation on the basis of which one first formed the intention. ${ }^{39}$ But Mario will have no reason to reconsider on such an account-in general, if things are going as expected, there will be no reason, and, in particular, the fact that it would be best for him not to act on his intention is no reason since (presumably) he was aware of that fact right from that start, but it did not stop him from forming the intention anyway. Second, according to a dispositional account, the rationality of reconsideration depends on whether the welfare-promoting habits of reconsideration would prompt reconsideration. ${ }^{40}$ But welfare-maximizing habits would not prompt Mario to reconsider-in general, such habits would not prompt reconsideration when things are going exactly as expected, and, in particular, if Mary can tell whether Mario really intends to enforce her rights, then she will be able to tell whether he is disposed to reconsider. It follows that Mario has no justification on either account for reconsidering, and so he rationally should not reconsider. Let us suppose that things proceed exactly as Mario expected, and he does not reconsider.

Finally, we note that these two statements together imply that Mario is rationally justified in enforcing Mary's rights over her driveway, even though doing so does not promote his own interests. For if one rationally forms an intention to act later (perhaps if some condition is satisfied), and rationally does not reconsider that intention up to the time of action, then it is rational for one to act at that time (if

${ }^{39}$ Cf. Gauthier, Commitment and Choice, supra note 6, at 231 ("So long as he has no reason to doubt the correctness of this expectation, he has no reason to reconsider.").

${ }^{40}$ See Mintoff, supra note 7, at 627-35 (discussing rational theories of (non) reconsideration). Bratman distinguishes three types of reconsideration (nonreflective, deliberative, and policy based) depending on what prompted the reconsideration (habits, deliberation, or policy). BRATMAN, supra note 27, at 60-61. He claims that a dispositional account is appropriate only for nonreflective (non) reconsideration. Id. at 64 . In my view, however, the rationality of having been prompted in these ways is itself dependant on habits of reconsideration, and so I take nonreflective (non) reconsideration to be the central case. See Mintoff, supra note 7, at 631 ("[T] he rationality of actions of reconsideration ... does not ultimately depend on deliberation about those actions but, rather, on the rationality of habits and dispositions."). This will be important when we come to apply these ideas to the discretionary enforcement of rights. 
that condition is satisfied). ${ }^{41}$ Consider, for example, the neighbor who decides late at night to park her car in Mary's driveway to save herself from a long cold walk from the nearest alternative parking space. Suppose Mario sees her; what should Mario do? Since Mario has rationally formed the intention to enforce Mary's rights should the occasion arise, and has rationally not reconsidered it, then, as he sees the neighbor get out of her car, this intention is rational. Since rational intentions provide a filter on the options over which one deliberates, however, his intention automatically excludes any options which entail not enforcing Mary's rights. Only those options consistent with enforcing Mary's rights remain, amongst which he should choose so as to best promote his welfare. He rationally should choose the best way of enforcing Mary's rights in this case (enforcing tactfully, say, rather than aggressively), even though this is not the best option available (staying inside out of the cold, rather than enforcing).

The correct response to the dilemma introduced in the previous Part, therefore, is to deny the inference contained in the first prong. The economic theory of rationality, recall, claims that the only sound, fundamental basis for rational appraisal is the promotion of the agent's welfare. ${ }^{42}$ But nothing follows about the appraisal of intentions or actions. It does not follow, and is not true, that an intention is rationally justified if it promotes the agent's welfare no less than any alternative-for it may require an action which departs too much from welfare promotion. And it also does not follow, and is also not true, that an action is rationally justified if it promotes the agent's welfare no less than any alternative-for not performing that action may be required by an intention whose adoption would more than compensate for the loss of welfare incurred by not performing that action. Rather, what is true is that an action is rationally justified when, amongst the relevant and admissible options (as determined by the background of rational intentions), it promotes the agent's welfare no less than any alternative.

${ }^{41}$ Mintoff, supra note 7, at 625; cf. BRATMAN, supra note 27, at 80 (introducing his historical principle of nondeliberative rationality for the basic case); Gauthier, Commitment and Choice, supra note 6, at 221 ("If I have adopted a plan and am reasonably not reconsidering it, then I have plan-based reasons for restricting my deliberation to actions compatible with my plan.").

${ }^{42}$ Supra text accompanying note 21. 


\section{UTILITARIANISM AND LEGAL RIGHTS}

So much for preliminaries. A proper understanding of the place of intentions within practical reasoning shows that the dilemma faced by the economic theory of rationality can be resolved. Can we harness this idea to show that the structurally similar dilemma faced by utilitarianism can also be resolved? That is the question for this final Part.

The dilemma, recall, consists of the following propositions: (1) utilitarianism implies that an institution or action is morally justified when it promotes human welfare no less efficiently than any alternative; and (2) the legal institutions granting rights which maximally promote human welfare will inevitably permit actions, respecting those rights, which do not maximally promote human welfare; but (3) morally justified legal rights automatically have moral force, in that it is always morally justified to respect them. ${ }^{48}$ How can the utilitarian respond? To answer this question, consider these propositions in reverse order.

\section{A. Do Morally Justified Legal Rights Have Moral Force?}

First, some deny (in effect) Lyons's "principal assumption" that morally justified legal rights always have moral force. Kent Greenawalt, in his comments on Lyons's paper, is happy to focus on legal rights (like Mary's) “whose establishment is morally defensible under a utilitarian standard" sions in which some member of the public, or even some official, is firmly convinced that the violation or nonenforcement of rights is the welfare-producing course, and that utilitarianism permits (or even requires) her to take that course. ${ }^{45}$ However, Greenawalt disagrees with Lyons's claim that people intuitively acknowledge a substantial moral constraint against violation or nonenforcement of any legal right which they think is morally justifiable. Greenawalt claims that people do not attribute moral force to morally justified legal rights.

In the first place, Greenawalt is not as distressed as Lyons seems to be about the violation of people's rights by members of the public. On the one hand, he says that if the right holder (Mary) cares about her right, knows about violations, and resents them, then we have a

${ }^{43}$ Supra pp. 850-52.

${ }^{44}$ Kent Greenawalt, Utilitarian Justifications for Observance of Legal Rights, in ETHICS, ECONOMICS, AND THE LAW: NOMOS XXIV, supra note 1, at 139, 141.

Id. at 142 . 
strong utilitarian argument against violations she will (or may) discover, since "no slight reason of personal convenience can provide a moral justification for violation, because minimal increments in utility cannot outweigh the basic utilitarian reasons in favor of compliance." However, if it is Mary's resentment of perceived violations of her right which is relevant to whether the right should be respected (and not the fact that the right is morally justified), then surely just as relevant will be the resentment many others may have toward the perceived impediment her right places on their activities (even if such resentment is not morally justified). This is, of course, an old problem for utilitarianism, but the fact that it is an old problem is evidence that Greenawalt has failed to capture people's intuitions on this point.

On the other hand, Greenawalt continues, if we knew we would do no damage, were sure we would not be seen, and thought that the owner would probably not mind, then we would have no real moral compunction against taking a shortcut across private land and committing a technical trespass in the process. "And if, contrary to every reasonable expectation, we came upon the owner and he expressed his annoyance, would our embarrassment and apology be accompanied by any real remorse?"47 Greenawalt is obviously well imbibed with the utilitarian spirit, for even though one of the conditions he places on the trespass is that we "thought... [that] the owner would probably not mind," utilitarian idea that the owner's consent (rather than her annoyance) is not relevant to the moral evaluation of whether to respect her rights. The owner's annoyance is just one more datum in the utilitarian calculation, a datum which may be overridden. However, it is again Greenawalt who has failed to capture people's intuitions, specifically the intuition that part of respecting a person is respecting her consent over the operation of her morally justified legal rights (within the type of limit Lyons identifies).

In the second place, Greenawalt is also not particularly disturbed by the nonenforcement of rights by officials, pointing out that " $[\mathrm{m}]$ any officials do not, in fact, afford citizens the complete benefits of their legal rights, and their actions are thought morally defensible." ${ }^{49}$ For example, if Mary is a fanatic about her legal rights, hears while on vacation in California that cars belonging to guests at her

\footnotetext{
${ }^{40}$ Id. at 145 .

${ }^{47}$ Id.

${ }^{48}$ Id.

${ }^{49}$ Id. at 142 .
} 
neighbor's party have blocked her driveway, and phones the police from out of state to ask them to move the cars, then (Greenawalt asks) cannot the police "justifiably refuse to act when the violation of the right seems so unimportant?"50 The key point is that there is a generally accepted discretion of some legal officials (police and prosecutors certainly, and Greenawalt suggests even judges in some cases) ${ }^{51}$ not to invoke the legal process, approval of which depends "partly on considerations of resource allocation, but also upon the belief that some technically criminal acts (even under ideally formulated penal provisions) simply do not warrant treatment as crimes." ${ }^{42}$ These considerations seem to show that, in some cases, it is morally justified not to enforce morally justified legal rights.

Greenawalt may be right to point to the importance of discretionary enforcement of legal rights, but, Lyons would respond, this shows nothing about their moral force. For we have seen that if Mary has a morally justified legal right to the exclusive use of her driveway, then it follows that she is morally permitted to use that driveway as she wishes (within limits), and others are morally permitted to use the driveway only with her permission (again, within limits). But this is all that follows about how Mary's legal rights make a moral difference. In particular, according to Lyons, nothing follows about the moral justifiability or otherwise of the enforcement of those rights; enforcement is not an essential feature of rights, not even legal rights. Rights can be recognized by law even when no legal provisions are made for their enforcement. "Consider, for example, those civil rights of U.S. citizens that are based upon the 'equal protection clause' of the Constitution [before the Civil Rights Act]." ${ }^{53}$ Actions respecting Mary's rights and actions enforcing those rights are distinct, and so their moral evaluation may also be distinct (a point utilitarians themselves will be familiar with). And so, even if officials are not morally required to enforce Mary's rights, it may still be that members of the public are morally required to respect them (even if doing so is not welfare promoting).

${ }^{50}$ Id. at 143 .

51 See id. at 144 (describing "the rare sort of situation in which a judge might conclude that the benefits of subverting a (morally) well-drawn law outweigh the damage that will be done").

${ }^{52} I d$. at. 143.

${ }^{53}$ Lyons, supra note 1, at 120. 


\section{B. Do the Best Institutions Permit Nonbest Actions?}

Second, some deny (in effect) the extent to which the best utilitarian institutions will permit (or require) actions which are not the best. Richard Hare, in his comments on Lyons's paper, distinguishes (much like the rule utilitarian) between intuitive thinking on practical matters, equivalent to everyday deliberation within some rule or institution, and critical thinking on such matters, equivalent to occasional (utilitarian) reflection about that rule or institution. ${ }^{54}$ He claims that this undermines Lyons's objection:

At the intuitive level most of what antiutilitarians say is correct; and at that level we do not need to, and shall often be wise not to, use utilitarian considerations, even if we are act-utilitarians. For we shall know that in all but the most extraordinary cases . . the most likely way of getting the optimific act is to follow our intuitions.

With respect to those extraordinary cases, "our intuitions com[ing] down in favor of respecting legal rights proves nothing." ${ }^{, 56}$ In short, the optimific institutions will inculcate moral intuitions (in judges, police, and the public) which, in all but the most extraordinary cases, will lead us to actions most likely to be optimific.

But is this true? Consider Mary's neighbor again. We saw that the optimific institutions grant Mary the exclusive use of her driveway and inculcate our intuition that Mary is morally permitted to use the driveway as she wishes. But, the optimific act is clearly for her neighbor to ignore this right and use the driveway without her permission. Hare does not explicitly address Mary's neighbor, but he is committed to thinking of this situation as a "most extraordinary case."

However, Hare offers no reasons for thinking that cases in which optimific institutions require nonoptimific actions are uncommon: "If I am asked how I know that most of our existing intuitions [including, presumably, our intuitions about Mary's rights] are such as to lead us to do optimific acts on the whole, I answer that I do not know, but think it to be so." ${ }^{57}$ But, as Lyons points out, we cannot assume that there is always a direct utilitarian justification for following morally

${ }^{54}$ See R.M. Hare, Utility and Rights: Comment on David Lyons's Essay, in ErHICS, ECONOMICS, AND THE LAW: NOMOS XXIV, supra note 1, at 148, 148 (pointing out "the distinction between different levels of moral thought, the intuitive and the critical").

${ }_{55}$ Id. at 152-53 (emphasis added).

56 $I d$, at 156 .

${ }^{57}$ Id. at 153 . 
justified rules. ${ }^{58}$ As we have seen, all institutions are necessarily imperfect, and some institutions (e.g., penal institutions) function best when focused on something other than promoting welfare. These are reasons for us to think that such cases are likely to be inevitable. ${ }^{59}$

\section{A Utilitarian Account of Legal Rights}

Finally, one might deny that the utilitarian idea really does imply that both institutions and actions are to be directly evaluated according to the utilitarian criterion. ${ }^{60}$ Our discussion above of the dilemma faced by the economic theory of rationality suggests that the appropriate response for the utilitarian may be to deny the inference contained in the first prong of the dilemma. Given the presumption that it makes sense to attribute intentions not just to individuals but also to the state, I want to suggest that a person has a legal right over something if and only if the state intends that she shall use it as she wishes (within limits) and intends that others will not use it without her permission (within limits). I shall defend both the presumption and claim in the remainder of the Article.

It makes sense to attribute intentions not just to individuals but also to the state because there are elements within the state which together play the characteristic roles of intentions within the individual. Just as an intention within the individual is a certain set of behavioral dispositions, so too the elements within the state are a certain set of behavioral dispositions of each of the officials within the legislature, the executive (in which I shall include the public service, regulatory authorities, etc.), and the judiciary (including the police, prosecutors, etc.). These dispositions may be the result of the operations of statutes or case law, though in this Article I shall focus only on the more

${ }^{58}$ Lyons, supra note 1, at 125-26.

59 See, e.g., RICHARD A. WASSERSTROM, THE JUdICIAL DECISION: TOWARD A THEORY OF LEGAL JUSTIFICATION 140-44 (1961) (using an example to demonstrate the reasons why an equitable utilitarian justification ultimately harms more than it helps); Alexander, supra note 8, at 318-19 (describing the lack of personal integrity and the focus on self-interest of utilitarianism); John Kilcullen, Utilitarianism and Virtue, 93 ETHICS 451, $452-53$ (1983) (comparing the costs and benefits of a utilitarian code with ones that have secondary guarantees of benevolence or honesty).

${ }^{60}$ For a similar utilitarian account of virtue, see Kilcullen, supra note 59, at 462

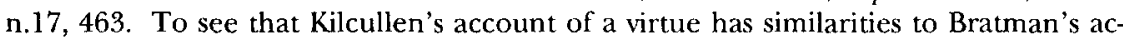
count of an intention, though Kilcullen's account is more moralized, compare $i d$. at 458 , discussing the preemption of calculation by virtue, with BRATMAN, supra note 27, at 33 , examining the background framework provided by intentions for deliberative calculation. 
straightforward examples offered by the former. It is important to note that the correlate of an individual's intention is not the laws of a state but rather is the set of behavioral dispositions of officials with respect to that law. For just as we distinguish between an individual's declaration of a plan and her intention having that plan as its object, so too we must distinguish between a law and what we might call the legal institution (this body of behavioral dispositions) having that law as its object.

So understood, legal institutions play the characteristic roles of intentions within an individual. To take them in reverse order, legal institutions involve practical reasoning. They are means-end coherent. From the perspective of the relevant officials, laws emanating from the legislature are often partial and typically get filled in with regulations by the executive. These are then filled in further by operational directives and official interpretations, which lead to specific intentions and actions of officials such as clerks and police.

Further, legal institutions are consistency constrained. The legal system as a whole seeks to make its laws consistent with one another (through legislative care in the drafting of laws and the judicial resolution of the nevertheless inevitable conflict between them) and consistent with social practicalities (through the disposition, for example, of the legislature not to enact laws which will be widely flouted).

Legal institutions are also revocably stable. Lacking any new considerations, officials at all levels within a state will typically retain the relevant behavioral dispositions up to those occasions which arise for acting upon them. As a result, legal institutions are conduct controlling. If a legal institution manages to survive until an occasion for acting upon it, and the relevant officials (for example, clerks or police) see that the occasion has arrived, and nothing external interferes with their actions, then, from the perspective of those officials, the relevant law, regulation, or directive will control and guide their actions on that occasion. In sum, just as the later time-slices of Mario's actions are related to the decisions made in earlier time-slices, so too the actions of lower officials of the state are related to the decisions made by higher officials.

Of course, these functions are not always perfectly fulfilled. For instance, some officials are corrupt, some laws are dead, the implementation of some laws is delayed, and some laws are sometimes inconsistent with others. In such cases, does a legal institution exist or not? The answer depends on what the state does in response to them. If it attempts to eradicate corruption in the administration of some 
law, then we should suppose an imperfect legal institution, rather than the absence of a legal institution, with respect to that law. If it does nothing about a long-dead statute, then we should suppose no legal institution at all, rather than a (very) imperfect one, with respect to that law. Just as an individual does not need to be perfect in order to have intentions, so too a state does not need to be perfect in order to have legal institutions serving the same functions.

We can now see how to resolve the dilemma for utilitarianism. Let us suppose-solely for the sake of argument-that the legislature enacts a law that no one is to prevent a person from using her driveway as she wishes (within limits) and that no one else is to use her driveway without her express permission (within limits); or, to save words, that each person controls her own driveway. Let us suppose further-what one hopes is actually the case-that there is the requisite respect for law amongst the executive and judiciary, in the sense that this enactment leads to the requisite behavioral dispositions among the relevant officials of the state. Given our understanding of intention, it follows that the legislature's enactment of that law is identical to the state forming an intention that a person shall control her driveway. Given Lyons's understanding of legal rights, it is also the case that the legislature's act enacting that law is identical to the state's act granting rights to a person over her driveway. Hence, as suggested above, a person's having legal rights is identical to the state's having the relevant intention. Depending on circumstances, then, it is consistent with utilitarianism for legal rights so understood to have all the features Lyons identifies.

First, a person's rights-let's focus on Mary's rights in particularclearly depend on social recognition or enforcement. The relevant state officials will have the relevant behavioral dispositions (for example, the police have the disposition to move cars infringing Mary's rights, and judges have the disposition to settle in her favor if the police are challenged, etc.), which constitute a very practical form of social recognition.

Second, Mary's rights also may be morally justified. Our legislators need to deliberate over a suitably wide (but finite) set of different possible laws that grant people different rights over their driveways and take into account a suitably wide (but finite) set of different possible circumstances in which these laws would operate. They also need to focus on the promotion of human welfare. However, if Lyons is correct that "real social rules that are supported by the best utilitarian ... arguments will require decisions in particular cases that would 
not most effectively promote [human] welfare," that any law will forgo some human welfare, either through acting upon it (if it is the one supported by the best utilitarian arguments) or through its being enacted (if it is not). But, since they are focused on promoting human welfare, our utilitarian legislators will choose that law which minimizes the amount of human welfare forgone, in much the same way as Mario chose that rule which minimized the amount of his own welfare forgone. And if they do, then Mary's rights will be morally justified.

Third, Mary's rights will have moral force. Suppose that our utilitarian legislators considered the type of case, mentioned above, in which a neighbor decides late at night to park his car in Mary's driveway to save himself a long, cold walk. ${ }^{62}$ Presumably, the indirect benefits of forbidding this type of behavior (greater rights) outweigh its direct benefits (avoiding inconvenience). Suppose that our utilitarian legislators realized this and that the relevant circumstances do not change in any way which would give the legislature (or any other official) a reason to think otherwise. In such a case, it is morally justified for the legislature to grant Mary rights which extend to this case, or, in other words, for the state to intend (amongst other things) to stop anyone using her driveway without her permission. But, just as the rationally justified intentions of an individual provide a filter on the options over which she later deliberates, so too the morally justified intentions of a state provide a filter on the options over which its officials deliberate. Thus, it is morally justified for the state actually to stop anyone from using Mary's driveway without her permission. And since no one is morally justified in stopping morally justified actions, it follows further that it is not morally justified for the neighbor to park in Mary's driveway without her permission (even though the result would, minimally, most promote human welfare). As such, Mary's rights do indeed have moral force.

Finally, however, the moral force of Mary's rights is limited (and, on this account, we get a criterion of where those limits are). Suppose that another type of circumstance considered by our utilitarian legislators was the one, also above, in which the driver of an emergency vehicle, on an urgent errand, blocks Mary's driveway without her per-

${ }^{61}$ Lyons, supra note 1 , at 123.

62 See id. at 116 (describing the neighbor hypothetical and concluding that Mary's legal rights are morally defensible against another's use of the driveway). 
mission. ${ }^{63}$ Presumably, the indirect benefits of forbidding this type of behavior (greater rights) is outweighed by its direct benefits (being able to deal with an emergency). In this case, our conclusions are exactly the opposite. It is morally justified for the emergency vehicle to park in Mary's driveway since doing so would most significantly promote human welfare.

Hence the correct response to the dilemma is, as before, to deny the inference in the first prong. Following Lyons, utilitarianism claims "that the only sound, fundamental basis for normative (or moral) appraisal is the promotion of human welfare." ${ }^{\text {"64 }}$ But it does not follow that an action is morally justified when it promotes human welfare more than any alternative. For there is a conceptual difference between evaluative appraisal ("this action is morally good, better than that one, etc.") and deontic appraisal ("this action is morally required, permitted, etc.") of actions. Thus utilitarianism, as Lyons defines it, is ambiguous between what we might call evaluative utilitarianism ("it is best to do what maximizes human welfare") and deontic utilitarianism ("one ought to do what maximizes human welfare"). Further, if Bratman is right about the role that intentions play in practical reasoning, evaluative utilitarianism does not entail deontic utilitarianism, for the best option available may not be relevant or admissible given the background of one's prior intentions.

So which is the real utilitarianism? Neither strictly follows from Lyons's definition. But if we are most impressed with the fundamental role human welfare plays in utilitarianism, then we might suggest that the correct interpretation of his definition is that utilitarianism claims that the final moral end is the promotion of human welfare. As we have seen, however, we may more effectively promote human welfare by intending to act independently of human welfare, within limits, than by intending to promote human welfare on each and every occasion. Hence, if we understand utilitarianism to be a claim about the final moral end, then it may well be that utilitarianism is true, even that evaluative utilitarianism is true, but that Lyons's definition that one always morally ought to do what maximizes human welfare is false. In other words, the basic utilitarian idea does not entail that the deontic status of an action should be determined in directly utilitarian fashion.

6.3 See id. at 115 (describing the emergency vehicle hypothetical and its resulting limitation on Mary's rights).

${ }_{64}$ Id. at 107 . 


\section{Some Objections}

I shall finish by considering some objections which may be leveled against this account.

The first objection I consider is a familiar one. In the course of his discussion, Lyons canvasses the rule-utilitarian response that institutions are morally justified to the extent that they promote human welfare, but actions are morally justified to the extent that they comply with morally justified institutions. ${ }^{6.5}$ Now, even if the basic utilitarian idea does not entail that the deontic status of an action should be determined in a directly utilitarian fashion, nevertheless not to do so seems to involve an ad hoc restriction on the application of that idea:

$[N]$ othing in the idea that welfare is to be promoted restricts the application of the standard of utility to social rules or institutions .... [Such a restriction] involves the addition of a factor that a utilitarian is not obliged to accept, either by the constraints of logic or by the normative implications of his theory. In the absence of such a factor, a utilitarian cannot ignore direct utilitarian arguments. ${ }^{66}$

The response to this objection is straightforward. For the considerations which justify ignoring human welfare given a morally justified legal institution mirror those which justify an agent ignoring her own welfare given a background of rational prior intentions. As we saw, Mario's rational decision to enforce Mary's rights over her driveway provides a filter over the actions he considers, and, in particular, the fact that it would promote his welfare to do nothing does not provide him with a reason to reconsider this intention or a reason to act otherwise than as he intends. Having considered this factor initially, it would be unacceptable double counting to allow it to influence him later. Similarly, the state's (the legislature's) morally justified decision to enforce Mary's rights also provides a filter over the state's (the police's) actions, and the fact that in certain cases (e.g., the neighbor late at night) human welfare is not promoted by such enforcement will not rationally influence the state's (the police's) behavior. Assuming the legislature had considered this type of case, it would be unacceptable for the police to usurp the deliberative role of the legislature. In sum, the police's refusal to be moved by the fact that it does not maximally promote human welfare to enforce the law betokens a completely rational refusal to continue paying attention to a consid-

${ }^{65}$ See id. at 126-31 (arguing that rule utilitarianism imposes an ad hoc restriction on the basic utilitarian idea).

Id. at 128 . 
eration which has already been dismissed by the legislature. And, it is important to note, this decision is not ad hoc; rather, if Bratman is right, it is an essential feature of any adequate account of practical reason. This is the additional factor which allows us to ignore direct utilitarian arguments.

A second objection derives from Lyons's comment that there is no necessary connection between the existence of legal rights and enforcement. Lyons claims that "enforcement is not an essential feature of rights, not even legal rights. Rights can be recognized by law even when no legal provisions are made for their enforcement." ${ }^{67}$ He offers the example of U.S. citizens' civil rights based on the Equal Protection Clause of the Constitution before the Civil Rights Act. However, if a person's legal right to something is identical to the state's intention for that person to enjoy exclusive use of the thing, and if any intention is by definition conduct controlling, then this legal right exists only if there is some disposition within the state to see to it that this person does indeed have exclusive use of the thing in question. That is, my account clearly implies that legal rights exist only if they are enforced.

Roughly speaking, this implication of my account seems right. To see why, we need to realize that the relation between the existence of a legal right and its enforcement mirrors the relation between an intention of an individual to perform some action and a belief she will, or will not, succeed. Now the fact that one intends some action does not entail that one will perform it; obstacles may happen to interfere. Nor does it entail that one believes one will perform that actionperhaps one is agnostic about whether one will try when the time comes or whether one will succeed if one tries. ${ }^{68}$ This situation suggests that the mere absence of the outcome the action aims to bring about, or the mere absence of a belief that such an outcome will be brought about, is no evidence in itself that one does not really intend that action. However, the fact that one intends some action does en-

${ }^{67}$ Id. at 120 .

68 See Gilbert Harman, Practical Reasoning, 29 REV. METAPHYSICs 431, 432 (1976) ("If one intends to do something it follows that one believes that one will do it ...."); J. David Velleman, Practical Reflection, 94 PHIL. REv. 33, 51 (1985) ("[T]o intend an action is simply to believe ... that one will perform it."). But see BRATMAN, supra note 27, at 37-38 (suggesting that the equating of intention with belief is an erroneously unattenuated connection); Hector-Neri Castaneda, Intentions and the Structure of Intending, $68 \mathrm{~J}$. PHIL. 453, 466 (1971) (arguing that the agent of an intention need not simultaneously consider the implications of her intention); R.F. Stalley, Intentions, Beliefs, and Imperative Logic, 81 MIND 18, 19-22 (1972) (distinguishing between two types of intentions, only one of which involves the resolution to succeed). 
tail, at the very least, that one believes one can perform it and that one does not believe one will not perform it. ${ }^{69}$ This means that awareness that one has not taken steps to ensure the ability to perform some action, or awareness of a disposition not to exercise that ability, provides strong evidence that one does not really intend to perform that action. In short, nonbelief in success is consistent with intention, but not disbelief.

We may apply these ideas to the relation between the existence of a given legal right within a given population and its enforcement. There are three cases we need to consider. First, the state may devote enough resources (educative or punitive) ${ }^{70}$ to secure everyone's right on every occasion. This case is hardly controversial: the state intends to enforce this right, and so this right exists for all. Second, the state may devote no resources at all to enforcement. In this case, the state will be aware that it cannot enforce this right for any member of the population and that it does not really intend to enforce this right at all, so this right exists for none.

Third, and more realistically, the state may devote only some resources to enforcement of a right, but not enough to completely secure everyone's right. This case itself splits into two. On the one hand, it may not be possible to identify beforehand who will, and who will not, have their rights enforced. If so, it may still be the case that this right exists for each member of the population. For example, consider some random member of that population. Admittedly, the state will probably not believe that it will enforce this person's rights; the state is aware it has not allocated enough resources for total enforcement. But nor will the state believe that it cannot or is disposed not to enforce this person's rights. It has, after all, devoted some resources to enforcement, and for all the state knows this person may be the beneficiary. This means, as we have seen, that we have no reason not to think that the state intends to enforce this person's right, so

${ }^{69}$ Again, this is a controversial issue beyond the scope of this Article. For the view that an intention entails no belief that one will not succeed, see BRATMAN, supra note 27, at 38-41; Frederick Adams, Trying: You've Got to Believe, 20 J. PHIL. Res. 549 (1995), but for the opposite view, see Carl G. Hedman, Intending the Impossible, 45 PHLOSOPHY 33 (1970); Kirk Ludwig, Impossible Doings, 65 PHIL. STUD. 257 (1992); I. Thalberg, Intending the Impossible, 40 AUSTRALASIAN J. PHIL. 49 (1962).

${ }^{70}$ Note that, just as Mario may secure Mary's rights by using a carrot or a stick, so too the state may see to it that people's rights are respected through education (administered by the executive) or punishment (administered through the judiciary), though for the purposes of this Article I shall refer to both as "enforcement." 
this right exists for that person, whoever she is." Randomly distributed partial enforcement is consistent with rights for each. On the other hand, it may be possible to identify the winners and losers in the enforcement lottery (because, for example, resources have been devoted to one locality rather than another). For reasons similar to those discussed in the first two cases above, the clearest way to describe the seeming discrepancy in this subcase is as follows: that the relevant right exists only for the favored subset of the population. Partial enforcement is consistent with rights for some, but entails no rights for others.

Thus, the appropriate response to Lyons's suggestion that there could be legal rights without enforcement depends on various empirical issues. If, before the Civil Rights Act, there was no enforcement at all (not even through other acts) of the civil rights based on the Equal Protection Clause, and if the state was aware that those rights were not being enforced yet did nothing about it, then the state did not really intend enforcement and, in my view, no such legal rights actually existed, pious statements notwithstanding.

This analysis leads to a third objection, deriving from Greenawalt's discussion of the discretionary enforcement of legal rights. His point, you will recall, was that there is a generally accepted discretion of some legal officials not to invoke the legal process based on considerations of resource allocation and beliefs regarding the status of criminal acts. ${ }^{72}$ However, if his contentions are correct, then the relevant mechanisms within the state are not, strictly speaking, concerned with enabling a person's right to exclusive use of whatever she has a right to, since discretion will often operate by ignoring a person's rights. That is, we would be mistaken to attribute an intention to the state.

However, the considerations Greenawalt raises are not inconsistent with attributing enforcement intentions to the state. The justifiability of discretion does not depend on utilitarian considerations as Greenawalt suggests but, rather, on considerations which mirror those relevant to the reconsideration of an intention.

${ }^{71}$ Note that the state does not intend that for each person, $x$, it will enforce $x$ 's right. The state is aware that it will not see to it that everyone's right is enforced since it has not allocated enough resources. Rather, for each person, $x$, the state does intend that it will enforce $x$ 's right. The state is not aware that it will not see to it that $x$ 's right is enforced, since it has allocated some resources to this. The conjunction of these two principles implies that for each person, $x, x$ has the relevant right.

${ }^{72}$ Greenawalt, supra note 44 , at 143. 
In some cases, discretion depends on actual authorization. Suppose that circumstances of the type Greenawalt describes had been considered during the initial deliberations of the utilitarian lawmakers. They may have agreed with Greenawalt that such violations are trivial when compared to enforcement costs and decided that in such cases police are to be given discretion. If so, we can all agree that exercising discretion in Mary's specific case would be morally justified. But utilitarian lawmakers may not have agreed. They may have thought that the violation was not trivial, that allowing discretion in such cases would complicate enforcement in more important cases, that it would be too difficult to specify the conditions under which discretion should be allowed, and so on. If they disagreed with discretion for one of these various reasons, it seems to me that exercising discretion would not be morally justified. Now, since Greenawalt is happy to admit that the welfare-promoting legal institutions may require the non-welfare-promoting respect of rights, he should be just as happy to admit that they may require the non-welfare-promoting $e n$ forcement of those rights. Discretionary powers are sometimes determined on the basis of actual authorization rather than utility.

In other cases, the moral justifiability of discretion may depend on what we might call "would-be" authorization, for it is not very likely that utilitarian lawmakers really will consider very specific types of cases such as the one involving Mary's neighbor. How should we deal with these cases?

At an individual level, we consider in advance only the most likely and most important circumstances, we specify in advance what we shall do in those circumstances, and then we rely on our capacity to reconsider intentions in dealing with any remaining cases which cause difficulties. There are two questions relevant here. First, what conditions should prompt one to reconsider an intention? Second, if prompted, what considerations are relevant in one's reconsideration? We have already seen the answer to the first question: one should reconsider an intention when welfare-promoting habits of reconsideration would prompt one to do so. The answer to the second question, in my view, is to extend the deliberation we performed right at the start: if prompted, we should treat the new case as if it had been considered at the start and should do whatever we would have decided to do originally. This treads a middle path between ignoring the new information we might have (which would be unwise) and entirely abandoning our intention and starting deliberation anew (which, given the 
inertia of intentions, will often not be possible and would, in any case, be wasteful of the deliberation we have already performed).

Similarly with regard to the enforcement of rights in difficult and unexpected cases. Police and enforcement officials should reconsider the enforcement of a right-and exercise discretion-when the welfare-maximizing habits of reconsideration would prompt them to do so. Moreover, if prompted, they should exercise discretion by considering what the utilitarian lawmakers would have required in that unforeseen situation had they considered it originally. ${ }^{73}$

Clearly, this account implies that unauthorized discretion could be morally justified, and some may see an objection in this. However, cases of morally justified unauthorized discretion are not likely to be widespread because the prevalence of such cases depends on exactly which discretionary habits maximize human welfare, and-while this is no doubt a thorny empirical issue-I am inclined to think that such habits will leave relatively little room for discretion, given the fragility of the artificial unity of the state. Nevertheless, there inevitably will be some cases of unauthorized discretion which my account implies are morally justified. But these, in my view, are the correct cases. In particular, if utilitarian lawmakers really would have permitted discretion had they considered some difficult case, then that part of the law-as-itactually-stands that forbids discretion is simply morally incorrect, and so it does not follow that police are morally unjustified in exercising discretion. If a legal institution has to be morally justified before acting in accord with its laws is morally justified, then a part of the legal institution (namely, the part forbidding discretion) has to be morally justified before acting in accord with its implications (not exercising discretion) is morally justified. uity:

${ }^{73} \mathrm{Or}$, as Aristotle puts it in his discussion of the relation between justice and eq-

When the law speaks universally, then, and a case arises on it which is not covered [correctly, context indicates] by the universal statement, then it is right, where the legislator fails us and has erred by over-simplicity, to correct the omission-to say what the legislator himself would have said had [h]e been present, and would have put into his law if he had known.

ARistotle, The Nicomachean Ethics 133 (J.L. Ackrill \& J.O. Urmson eds., David Ross trans., Oxford Univ. Press paperback ed. 1980). 
* * * * * * * * 